\title{
The Conservation Effects Assessment Project benchmark watersheds: Synthesis of preliminary findings
}

\author{
C.W. Richardson, D.A. Bucks, and E.J. Sadler
}

\begin{abstract}
The Conservation Effects Assessment Project was established to quantify the environmental impacts of USDA conservation programs. The Conservation Effects Assessment Project involves multiple watershed assessment studies designed to provide a scientific basis for a national assessment. The USDA Agricultural Research Service established 14 research sites-benchmark watersheds-to measure regionally specific environmental quality effects of conservation practices and to improve and validate models used by the USDA Natural Resources Conservation Service for their national assessment. Within each watershed, data were collected and continue to be collected to provide insight into the effects of specific conservation practices implemented under programs such as the Environmental Quality Incentives Program and the Conservation Reserve Program. A data storage and management system, Sustaining the Earth's Watersheds-Agricultural Research Data System (STEWARDS), was developed to provide easy accessibility to these data for analysis. Models were validated using data from many of the watersheds and were shown to be valuable tools for extrapolating the results for a national assessment. The physical process models were also combined with economic models to optimize tradeoffs among environmental and economic objectives of conservation practices. The benchmark watershed studies have begun to identify the effects of selected conservation practices, although additional data are required to provide definitive results. A prototype of a new modular modeling system has been developed that will provide a more powerful tool for future analyses. The initial Conservation Effects Assessment Project findings and products demonstrate progress toward the overall goals of quantifying conservation practice effects and providing tools to transfer the knowledge to points where they are applied under future conservation policy.
\end{abstract}

Key words: Conservation Effects Assessment Project (CEAP)—conservation practiceseconomics - environmental quality-models — water quality

The USDA has provided technical assistance and cost sharing to farmers and ranchers for implementing conservation practices on privately owned working lands since the 1930 s. The primary purpose of the assistance programs has been to "improve the productivity of US farms and ranches and to protect the 'natural resource base' that sustained the agricultural enterprise" (Cox 2006). Conservationists have recognized for many years that these conservation programs protect millions of acres of farm and ranch lands from degradation. Research over the past fifty and enhancing environmental quality. The public concern has also led to numerous studies of the effects of agriculture and other nonpoint sources on environmental quality (Knisel 1980; Baker 1992; Phillips et al. 1993; Stone et al. 2003). The 1989 USDA Presidential Initiative on Water Quality established water quality objectives and provided impetus for a national research and assessment endeavor called the Management Systems Evaluation Areas (MSEA) as part of a multi-agency USDA Water Quality Program (USDA 1994). These studies began efforts to quantify environmental effects of conservation practices at the field scale, but the effects have not been adequately quantified at the watershed scale where the primary public benefit is realized.

The public policy context surrounding this issue was changed significantly by the Farm Security and Rural Investment Act of 2002 (known as the 2002 farm bill). Driven largely by environmental concerns, it authorized a substantial increase in funding for existing USDA conservation programs, including the Environmental Quality Incentives Program (EQIP) and the Conservation Reserve Program (CRP). The 2002 farm bill also authorized funding for a new conservation program-the Conservation Security Program. Overall, the 2002 farm bill authorized federal expenditures for conservation practices on farms and ranches in the United States at a level about $80 \%$ above that of the previous farm bill.

The increase in authorized funding for conservation programs mandated that the US Secretary of Agriculture conduct a study to quantify the environmental benefits of conservation practices and to provide farmers, conservationists, and the general public an accounting of the value of public expenditures for conservation programs. Several USDA agencies

Clarence W. Richardson is a retired agricultural engineer, USDA Agricultural Research Service (ARS), Temple, Texas. Dale A. Bucks is a retired agricultural engineer, USDA ARS, Beltsville, Maryland. E. John Sadler is a supervisory soil scientist, USDA ARS, Columbia, Missouri. 
are involved in a project to quantify the benefits. The project, known as the Conservation Effects Assessment Project (CEAP), is designed to improve our ability to quantify the environmental effects of conservation practices applied to agricultural land and to provide an assessment of the value of conservation programs. Quantifying the environmental effects or benefits of the programs will assist policymakers and program managers in implementing and modifying existing programs and designing new programs that can more effectively, efficiently, and economically meet public demands and the goals set forth by Congress in the 2002 farm bill.

The USDA Natural Resources Conservation Service (NRCS) and Agricultural Research Service (ARS), along with other federal agencies, are conducting CEAP studies to quantify the environmental benefits of conservation practices implemented through conservation programs on working and retired cropland, grazing land, agro-forest land, and wetlands. The CEAP studies have two major components:(1) a national assessment and (2) watershed assessment studies. The national assessment, conducted primarily by USDA NRCS, tracks environmental benefits over time on a national scale using past and current data and watershed-scale models. The watershed assessment studies are designed to provide detailed data of environmental effects in selected regions of the country, evaluation and improvement of the national assessment models, and research on the effects of specific conservation practices at the watershed scale. The findings from the two components of CEAP will be the basis for reports and documents that describe for Congress and the American public the environmental benefits of publicly funded conservation programs.

Conservation Effects Assessment Project Watershed Assessment Studies. Three categories of the CEAP watershed assessment studies are being conducted:

\section{USDA ARS benchmark watersheds.}

The ARS is conducting CEAP research on 14 watersheds in various regions of the country. The land use on the benchmark watersheds is primarily agricultural cropland that is rain-fed. On some of the watersheds ARS had long-term research underway before the initiation of CEAP.The CEAP research involved obtaining data describing land management practices and physical data such as water quality and quantity, ecosystem changes, and economic outcomes.

2. USDA NRCS special emphasis watersheds. Ten watersheds were selected to address specific resource concerns such as manure management for animal feeding operations and water use on irrigated cropland, or other special land use activities. The special emphasis watershed studies are managed by NRCS, and data are being obtained to support evaluation of the specific resource concerns.

3. USDA Cooperative State Research, Education, and Extension Service competitive grants program watersheds. These watersheds were selected by the USDA Cooperative State Research, Education, and Extension Service through the Water Quality Initiative Competitive Grants Program. This program sponsors a collection of watershed case studies that will use existing streamflow and contaminant load data to investigate the linkages among various conservation and land management practices and the resultant effects on water quality. These watersheds were selected incrementally beginning in 2004 with a total of 14 watersheds having been selected by 2006 .

The watershed assessment studies support the USDA NRCS national assessment by providing a science base for effective, sustainable management of agricultural landscapes for improved environmental quality (Cox 2007). The studies are also improving and validating the models used to quantify the environmental effects of conservation programs.
This special issue of the Journal of Soil and Water Conservation provides results that have been obtained through the USDA ARS benchmark watershed program from 2004 through 2007. Papers in this issue provide detailed background and results on a watershed basis. This paper summarizes the salient findings from across the spectrum of watersheds.

Objectives of the Agricultural Research Service Benchmark Watershed Assessment Program. The primary objective of the USDA ARS benchmark watershed assessment program is to support the national assessment by providing detailed research findings for a few intensively studied watersheds and to provide a framework for evaluating and improving the performance of models for future assessments. The specific objectives of the USDA ARS benchmark watershed assessment studies are as follows:

1. Develop and implement a system to compile, organize, and document water, soil, management, weather, and socio-economic data for assessment of conservation practices.

2. Measure water quality and quantity, soil quality, and ecosystem effects of conservation practices at the watershed scale in a variety of regional settings.

3. Validate models and quantify uncertainties of model predictions at multiple scales.

4. Develop policy-planning tools to aid selection and placement of conservation practices for optimal environmental quality, farm profitability, and conservation practice efficiency.

5. Develop new and improved regional watershed models for quantifying environmental outcomes of conservation practices in major agricultural regions.

\section{Materials and Methods}

Fourteen watersheds were selected for the USDA ARS benchmark watershed studies (objective 1). The watersheds were at different stages of research implementation at the beginning of CEAP, ranging from little or no existing data to fully 
Table 1

Resource measurements on USDA Agricultural Research Service benchmark watersheds.

\begin{tabular}{|c|c|c|c|c|c|}
\hline \multirow[b]{2}{*}{ Watershed } & \multicolumn{5}{|c|}{ Resource measurements } \\
\hline & Water quality & Water quantity & Soil quality & Ecosystem & Economics \\
\hline South Fork lowa River, lowa & $x$ & $x$ & $x$ & $x$ & \\
\hline St. Joseph River, Indiana & $x$ & $x$ & $x$ & & $\mathrm{x}$ \\
\hline Upper Big Walnut Creek, Ohio & $x$ & $x$ & $x$ & $x$ & $x$ \\
\hline Mark Twain Lake/Salt River Basin, Missouri & $x$ & $x$ & $x$ & $x$ & $x$ \\
\hline Choptank River, Maryland & $x$ & $x$ & $x$ & & \\
\hline Goodwin Creek, Mississippi & $x$ & $x$ & $x$ & $x$ & \\
\hline Beasley Lake, Mississippi & $x$ & $x$ & $x$ & $x$ & \\
\hline Yalobusha River, Mississippi & $x$ & $x$ & $x$ & $x$ & \\
\hline Little River, Georgia & $x$ & $x$ & $x$ & & \\
\hline
\end{tabular}

implemented research. This is a natural outcome of the establishment history of USDA ARS watersheds. Some of the watersheds were established in the 1950s and 1960s as part of a regional watershed laboratory initiative, and some were established during the MSEA studies (USDA 1994). Still others were established around these legacy sites as part of a scaling-up to meet CEAP requirements. Conservation practices were applied, in varying degrees, on all 14 watersheds.

Processes measured on the watersheds (objective 2) varied depending on local needs. In general, data on stream contaminants such as phosphorus $(\mathrm{P})$, nitrogen $(\mathrm{N})$, suspended sediment, commonly used pesticides, and biological contaminants were collected to quantify the effects of conservation practices on water quality. On some watersheds, data were obtained on ecosystem changes and economic outcomes. The 14 USDA ARS benchmark watersheds and the types of watershed response data obtained on each watershed are given in table 1. The geographic locations of the watersheds are shown on figure 1.

The primary models evaluated and validated for use in CEAP (objective 3) are the Soil and Water Assessment
Tool (SWAT) (Arnold et al. 1998) and the Annualized Agricultural Non-Point Source (AnnAGNPS) model (Bingner and Theurer 2001). Both models can be used to assess the impact of arbitrary conservation practices on water quality and quantity.

The SWAT model is a river basin or watershed-scale model developed to predict the impact of land management practices on water, sediment, and agricultural chemical yields in large complex watersheds with varying soils, land use, and management conditions. The SWAT model is physically based and requires specific information about weather, soil properties, topography, vegetation, and land management practices within the watershed. The physical processes associated with water movement, sediment movement, crop growth, nutrient cycling, and other processes are modeled using these input data.

The AnnAGNPS model is designed to assess the watershed effects of conservation management practices on water, sediment, and dissolved chemicals; the development of total maximum daily load limits; and for conducting risk and cost-benefit analysis. These objectives are met by describing the spatial variability of climate, soil properties, topography, and agricultural management practices. The AnnAGNPS also provides the capability to track any pollutant to any point in the watershed, allowing for the assessment of appropriate conservation measures to resolve the particular pollutant problem. Both SWAT and AnnAGNPS were tested on many of the USDA ARS benchmark watersheds.

The development of policyplanning tools (objective 4) was approached in CEAP in two ways. First, basic economic and social studies were conducted on three selected watersheds through agreements with university cooperators. Second, policy tools were developed that can be used to assist in selecting and placing conservation practices to optimize profits, environmental quality, and other tasks as part of the evaluation of conservation practices. These policy tools were envisioned as a means to help policy makers and program managers optimize investments in conservation programs to meet environmental goals and address alternatives in food, fiber, and fuel production needs. The plan calls for using the findings from the basic economic and social studies and other related economic research within 


\section{Figure 1}

Location of USDA Agricultural Research Service benchmark watersheds.

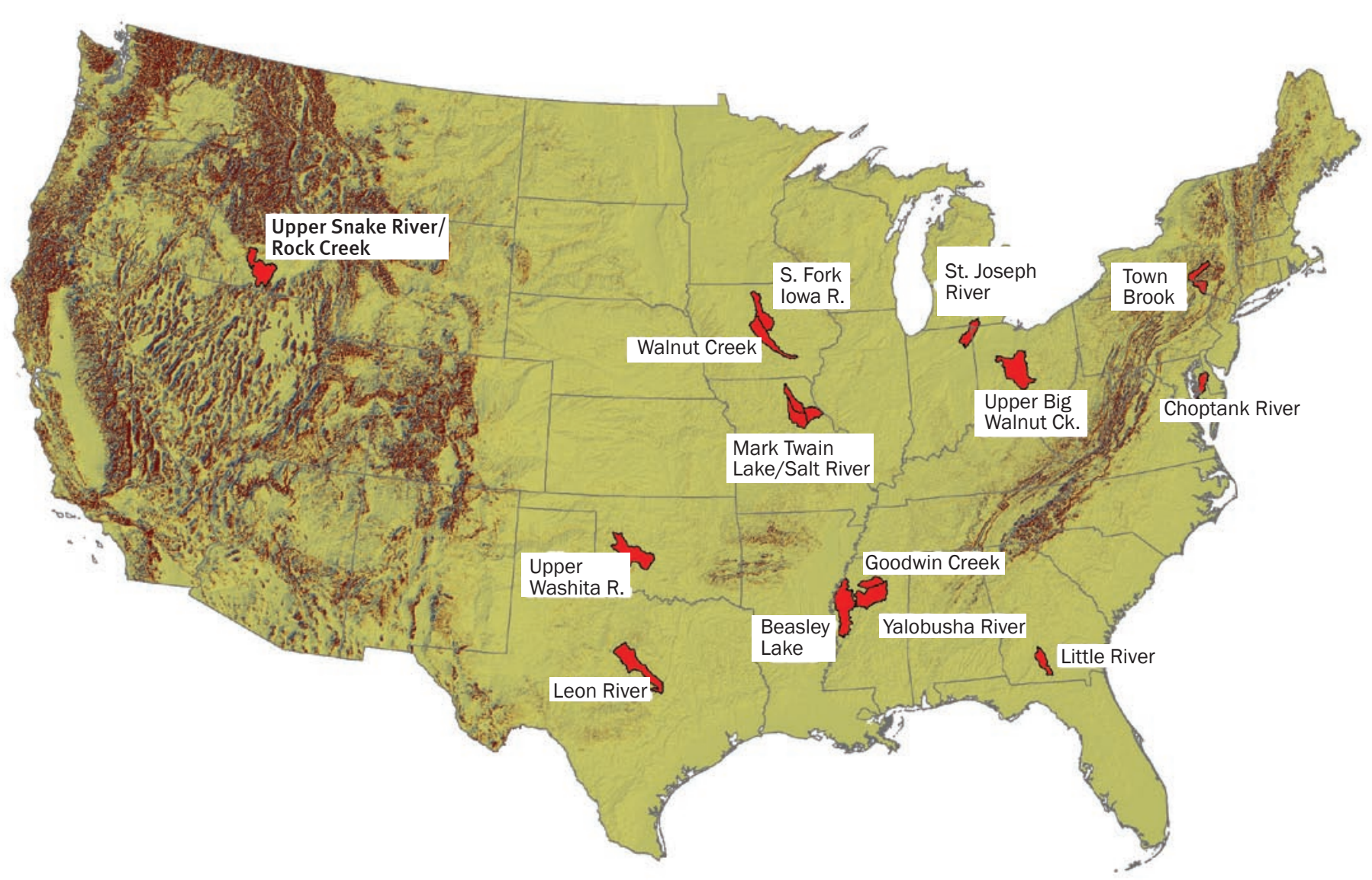

the CEAP effort to improve these policy tools at a later date.

Dominant hydrologic processes vary among regions of the country, as well as agricultural systems and management and environmental responses to agriculture. These regional differences influence the nature of conservation practices that can be effectively applied. Therefore, customized watershed models are needed for specific regions. Objective 5 is focused on developing object-oriented, modular models to address region-specific environmental responses that are capable of scaling up from fields to watersheds.

The five objectives were highly integrated. Field research on the 14 watersheds as well as model and data-system development required a carefully coordinated approach. The project involved over 60 scientists spread across numerous field locations. Six teams were organized to conduct the research and provide project coordination. The six teams and their responsibilities are described below:

1. Data Management. Responsible for developing a data system for storing and managing data collected on the watersheds and from other sources. Also responsible for working with field locations to populate the data system with watershed data.

2. Watershed Design for Determining Environmental Effects. Responsible for designing methods and collecting basic resource data on the watersheds, and for interpreting the data to determine the effects of conservation practices on environmental quality.
3. Model Validation and Uncertainty Analysis. Responsible for developing model validation standards, for validating and improving models to be used in the national assessment, and for determining levels of uncertainty of model estimates.

4. Economic Analysis. Responsible for developing economic model approaches for estimating cost-effectiveness of combinations and placement of conservation practices on watersheds. Also responsible for conducting economic analysis on selected watersheds.

5. Model Development and Regionalization. Responsible for developing state-of-the-art modeling capabilities for estimating conservation effects on a regional basis. The regional models address essential processes of impor- 
tance to a particular region of the country.

6. Data Quality and Assurance. Responsible for determining standardized protocols for collecting resource data on the watersheds and for documenting quality assurance and control methods for laboratory analysis.

The six teams were responsible for coordinating the research on the five objectives and delivering useful products relative to the effects of conservation practices on environmental quality. Results to date for each objective are given below. In addition, the results of a special study on selected watersheds to determine the source of sediment within each watershed and to define channel contributions to sediment loads is described below.

\section{Objective1 Results: Data Management System Development}

The extensive body of information about the environmental effects of conservation practices collected in CEAP is valuable only to the extent that the data and supporting information are accessible to users. One of the prime objectives of the USDA ARS benchmark watershed studies is to develop and implement a Webbased system that would make the data readily available. An effort to build a database that would make the ARS watershed data more useful and easily available was underway before CEAP began (Steiner et al. 2003). With the beginning of CEAP, the database effort was expanded in scope and incorporated into CEAP. The database was designed to provide access to soil, water, climate, land-management, and socio-economic data from all 14 ARS benchmark watersheds, as well as data from the other CEAP watersheds as available.

The Sustaining the Earth's WatershedsAgricultural Research Data System (STEWARDS) has been developed and the beta version was released to the data managers and researchers in July 2007. The STEWARDS system consists of (1) a centralized site with Web servers and application software including a database management system and a geospatial data access portal, (2) watershed measurement data, geographic information system layers (topography, land use, imagery, and descriptive layers), and metadata, (3) users, and (4) watershed sites that are sources of data. The beta version contains partial data from four of the ARS benchmark watersheds, and the process for adding data for other watersheds is in place. The current and ongoing focus of the development team is to bring additional watersheds' data into the system. The STEWARDS system also includes means to store results of various key model calibration and validation studies. Release of the beta version is a significant step in organizing and managing basic data relative to the effects of conservation practices and in making the data available to researchers, policymakers, and others (Steiner et al. 2008a; Sadler et al. 2008).

\section{Objective 2 Results: Watershed Studies}

South Fork Iowa River, Iowa. The South Fork of the Iowa River, located in northcentral Iowa, is an area of intensive crop and swine production. Agriculture production covers about $90 \%$ of the watershed with corn and soybean as the crops. Each year $30 \%$ of the cropland receives manure application from the swine production facilities, in rotation prior to corn. Conservation practices focus on residue management systems such as notill or mulch-till. Grassed waterways and riparian buffers are often used as edgeof-field practices (Tomer et al. 2008b). These conservation practices target surface runoff as a method of controlling pollutant transport. However, most of the area is tile drained. The tile drainage systems dominate the hydrologic budget and provide a transport pathway for nitrate and dissolved $\mathrm{P}$ that is unaffected by the surface conservation systems. Nitrate losses occur through the tile drainage systems with nitrate export often exceeding $20 \mathrm{~kg} \mathrm{ha}^{-1} \mathrm{y}^{-1}\left(18 \mathrm{lb} \mathrm{ac}^{-1}\right.$ $\left.\mathrm{yr}^{-1}\right)$. Surface runoff conservation prac- tices such as residue management and riparian buffers are unlikely to have substantial impact on nitrate losses through the tile drains. Controlled drainage and nutrient removal wetlands are among those practices that could reduce $\mathrm{N}$ and $\mathrm{P}$ loads in tile drainage outflow (Green et al. 2006; Tomer et al. 2008a).

Concentrations of $\mathrm{P}$ in streams are large enough to impact stream ecology through eutrophication. E. coli populations are large enough to impair use of the waterways for contact recreation during much of the summer, but patterns do not always support the assumption that manure is the major source. Riparian buffers and grassed waterways should mitigate runoff pollutant losses, but conservation systems need to better address pollutant sources and transport pathways that are specific to each contaminant (Tomer et al. 2008a).

Walnut Creek, Iowa. The Walnut Creek watershed, located in central Iowa, has a drainage area of 5,130 ha $(12,700 \mathrm{ac})$ and a mean annual rainfall of about $820 \mathrm{~mm}$ (32 in). The topography is gently rolling and poorly drained with numerous closed depressions or potholes. The soils are mostly fine-textured and poorly drained. About $60 \%$ of the area is tile drained due to poor surface drainage. Over $80 \%$ of the watershed is in cropland with corn and soybean as the primary crops. Fertilizer $\mathrm{N}$ is usually applied in the fall at rates averaging about $150 \mathrm{~kg} \mathrm{~N} \mathrm{ha}^{-1}(134 \mathrm{lb} \mathrm{N}$ $\mathrm{ac}^{-1}$ ) to fields that will be planted to corn the following spring. Pesticides (primarily atrazine on corn) are also commonly applied to crops. Environmental monitoring began on Walnut Creek in 1991 under the MSEA program. Nitrate in streamflow is the primary contaminant, with nitrate concentrations often exceeding drinking water standards. Pesticide losses in streamflow are small, but atrazine concentrations occasionally exceed drinking water standards (Jaynes et al. 1999). Constructed wetlands were found to reduce $\mathrm{NO}_{3}-\mathrm{N}$ fluxes up to $30 \%$ from tile-drained subbasins, but were not capable of effectively reducing $\mathrm{NO}_{3}-\mathrm{N}$ in larger flows (Tomer et al. 2003). 
The SWAT model was modified for use in Walnut Creek to improve the simulation of tile and pothole topography. The SWAT model was calibrated and validated using the data collected in Walnut Creek to simulate monthly surface and subsurface flows, corn yields, and corn nitrate uptake. Monthly $\mathrm{N}$ and atrazine loads in streamflow were accurately simulated after these modifications were made (Du et al. 2005, 2006). The SWAT model simulations showed that splitting $N$ fertilizer application with the first application shortly before corn planting and the second application when corn plants are 15 to $30 \mathrm{~cm}$ (6 to 12 in) high reduced $\mathrm{NO}_{3}-\mathrm{N}$ loss by more than $20 \%$ compared to the conventional fall application (Saleh et al. 2007).

St. Joseph River, Indiana. The St. Joseph River watershed has a 2,830- $\mathrm{km}^{2}$ $\left(1,105-\mathrm{mi}^{2}\right)$ drainage area located in three states: Indiana, Michigan, and Ohio. The watershed contains intensive agricultural activities with $64 \%$ of the area in cropland, $15 \%$ in pasture or forage, $10 \%$ in forest or wetlands, and $11 \%$ in urban or industrial use. The mean annual precipitation is about $900 \mathrm{~mm}$ (35 in), and the predominant crops are corn and soybean. The soils are primarily silt loams to clay loams. The landscape is dominated by closed depressions and requires extensive surface drainage for successful crop production. Two types of surface drain inlets are common: (1) vertical risers and (2) blind inlets that use coarse material at low spots of depressions. Both types of surface drain inlets transmit surface runoff water to subsurface tile drains where surface flow is mixed with subsurface flow (Smith et al. 2008). Water from the tile drains ultimately flows into the drinking water for the city of Ft. Wayne, Indiana. The primary environmental issues related to agriculture are pesticides (primarily atrazine), nutrients, and sediment in runoff entering water supplies. Pappas et al. (2008) found that on the Cedar Creek watershed, a $708 \mathrm{~km}^{2}$ $\left(277 \mathrm{mi}^{2}\right)$ subwatershed of the St. Joseph River, daily sampling with more intensive sampling during storm events is need to assess the effects of management practices on reducing atrazine and other herbicides in streamflow.

The SWAT and AnnAGNPS models were applied to the Cedar Creek watershed to simulate streamflow, sediment transport, and atrazine losses. Both models were applied without calibration to eliminate bias due to parameter estimation. The SWAT model performed better than AnnAGNPS in estimating monthly and annual streamflow. The AnnAGNPS model predicted substantially greater sediment in the stream than SWAT and was unsuccessful in estimating atrazine loss. The SWAT model was calibrated for streamflow and atrazine in the Cedar Creek watershed and was shown to be an effective tool for simulating the dynamics of streamflow and atrazine concentrations (Larose et al. 2007; Heathman et al. 2008).

Upper Big Walnut Creek, Ohio. Upper Big Walnut Creek, located in central Ohio, has a $492-\mathrm{km}^{2}\left(192-\mathrm{mi}^{2}\right)$ watershed that drains into a reservoir that supplies domestic water for Columbus, Ohio, and surrounding communities. The land use in the watershed is $60 \%$ cropland with the remainder of the area in forest or urban use. The primary crops are corn, soybean, and wheat, and the cropland is extensively tile drained. The tile drainage systems provide a direct conduit to transport nutrients, pesticides and other contaminants directly from cropland to streams. In addition, some of the subwatersheds have been channelized (streams shaped and straightened) while the streams of other subwatersheds have been left in their natural condition (unchannelized) (King et al. 2008). A portion of the watershed is undergoing a transition from cropped to urban use with the construction of dwellings, parks and golf courses. Some of the streams within the Upper Big Walnut Creek watershed are impaired by nutrients, pesticides, pathogens, and habitat degradation resulting from agricultural activities and/or contaminants from urbanization activities (Ohio Environmental Protection Agency 2003, 2004).
A paired of channelized and a pair of unchannelized watersheds in the Upper Big Walnut Creek watershed were identified to study the effects of conservation practices on water quality. The paired watershed approach increased the sensitivity for determining the effects of these conservation practices on suspended solids and nutrient and pesticide concentrations and loads (King et al. 2008). Similarly, guidelines were developed for conducting studies of the effects of these conservation practices on fish and macroinvertebrate communities in agricultural drainage ditches (Smiley et al. 2008). These procedures present valuable methodologies for analyzing the effects of conservation practices on environmental quality in the Upper Big Walnut Creek watershed and other CEAP watersheds.

Mark Twain Lake/Salt River Basin, Missouri. The Mark Twain Lake/Salt River Basin watershed is in northeastern Missouri within the Central Claypan region. The $6,600-\mathrm{km}^{2}\left(2,580-\mathrm{mi}^{2}\right)$ basin drains into Mark Twain Lake, which is the major source of domestic water for the region. The basin has flat to gently rolling topography and shallow claypan soils that restrict vertical movement of water, resulting in a high runoff potential. The primary crops are corn, soybean, wheat, and sorghum. Both beef cattle and swine are produced within the watershed, with swine operations increasing. The primary environmental problems are loss of soil through erosion and the contamination of the reservoir by sediment, nutrients, pathogens, and herbicides. Hydrologic and environmental quality data have been collected in the watershed in three phases. The initial infrastructure for hydrology in Goodwater Creek, a subwatershed of the Salt River, was installed in 1971 and expanded to include environmental quality sampling in 1991 as part of the MSEA project. Scaling up to the Mark Twain Lake/Salt River Basin for CEAP included 12 additional sites for flow monitoring and water quality sampling, which started in 2005. 
The naturally formed subsurface claypan in the watershed creates a barrier to percolation and promotes runoff, resulting in a vulnerability to erosion and the runoff of sediment and herbicides to streams. Corn and soybean herbicides are frequently detected in streamflow. Mark Twain Lake was on the original 303(d) list for impaired waters for atrazine (Missouri Department of Natural Resources 1998). This designation was removed in 2003, although two streams in the region continue to be monitored for atrazine during the re-registration process.

Numerous conservation practices have been applied in the area. No-till cropping systems have not reduced runoff due to the dominant role of the restricting claypan. The lack of incorporation of herbicides with no-till has led to an increase in runoff of surface applied herbicides. However, vegetative buffer strips have been effective in reducing the transport of both dissolved and sediment bound herbicides in surface runoff. Perennial grasses established through CRP have significantly improved infiltration and soil quality relative to conventional cropping systems. The SWAT model was successfully used to simulate the impact of grass waterways in reducing herbicide concentrations and in simulating long-term herbicide concentration trends in streamflow (Lerch et al. 2008).

Town Brook/Cannonsville Reservoir, New York. The Cannonsville Reservoir watershed is located about $160 \mathrm{~km}(100$ mi) northwest of New York City and is a major component of New York City's drinking water supply. The main contaminant in the watershed is P loading and its effect on the reservoir. Research to quantify the effects on P loads of stream bank fencing, precision feeding, and use of cover crops has involved a combination of field experimentation, monitoring, and modeling conducted primarily within the Town Brook watershed, a subwatershed representative of conditions in the larger Cannonsville Reservoir watershed.

Land use within the Cannonsville Reservoir watershed is approximately
49\% agroforestry and 48\% grass and hay production. About 230 confined animal feeding operations (primarily dairies) are contained within the 3,700-ha (1,500-ac) watershed. A voluntary, incentive-based collaborative program was implemented in 1992 among producers and state, federal, and local organizations to reduce $\mathrm{P}$ loads to the reservoir. Conservation practices generally employed are those most typically recommended by USDA NRCS for the region, including, but not limited to barnyard improvements, nutrient management plans, precision feeding, conservation crop rotation, contour buffer strips, filter strips, forage harvest management, grassed waterways, stream bank fencing, and wooded riparian buffers. Water quality monitoring data confirm that conservation practices implemented through a $100 \%$ cost share program have lowered $\mathrm{P}$ loads from non-point sources to the Cannonsville Reservoir by $50 \%$ in dissolved $\mathrm{P}$ and $17 \%$ in total P (Bishop 2006).

Watershed simulation models were used to predict long-term effects of conservation practices in the watershed on water quality. The Variable Source Loading Function model was shown to be capable of identifying target areas for conservation practice implementation. The SWAT model was successful in predicting the impact of conservation practices on streamflow, sediment load, dissolved P, and total P. An optimization technique was developed using SWAT to select conservation practices for reducing $\mathrm{P}$ loadings. Using the technique, the most cost-effective selection of conservation practices for reducing $\mathrm{P}$ loads could be identified (Bryant et al. 2008).

Choptank River, Maryland. The Choptank River is an estuary and tributary of the Chesapeake Bay. The 2,057- $\mathrm{km}^{2}$ (804-mi ${ }^{2}$ ) watershed is on the Delmarva Peninsula. The drainage originates in Delaware, flows into Maryland and eventually discharges into the Chesapeake Bay on Maryland's eastern shore. The CEAP research on the Choptank is an important component of a multi-agency effort to improve water quality in the bay.

Land use in the Choptank watershed is about $52 \%$ agriculture, $26 \%$ forest, and $5 \%$ urban. The agricultural land is used primarily for production of corn, soybean, wheat and barley. There are also small- to medium-sized animal feeding operations with poultry production the most prevalent type. Poultry litter is routinely recycled as fertilizer on corn and soybean fields. A large portion of the producers participate in a nutrient management plan.

The impacts of stream water quality on aquatic ecosystems resulting from nutrient, sediment, and bacterial contamination are the most critical environmental problems associated with agriculture. However, pesticides and other contaminants are also important. Agricultural producers in the Choptank watershed are receiving conservation assistance through several USDA programs as well as programs provided by the Maryland Department of Agriculture.

Remote sensing techniques and ground measurements have been used to assess the effectiveness of cover crops for sequestering nutrients. Small grain crops have been a cost-effective practice for keeping excess nutrients in the fields following crop harvest and in reducing nutrient losses to the Chesapeake Bay. The SWAT and AnnAGNPS models have been used to quantify the environmental benefits of implementing cover crops and riparian buffers on the Choptank watershed. Data from a subbasin were used to calibrate and validate the models. The models showed a direct relationship between degree of implementation of cover crops and the reduction in nitrate loading to the stream. The SWAT model showed marked improvement in load reduction when cover crops were targeted to areas with the greatest nitrate loads rather than randomly applied. The AnnAGNPS model showed no significant reduction in nitrate loading when $40 \%$ of the cropland was planted to winter cover crops but had a substantial reduction when $75 \%$ of the cropland was planted to cover crops. The 
AnnAGNPS model was used to identify the spatial location for specific pollutant loads within the watershed (McCarty et al. 2008).

Goodwin Creek, Mississippi. Goodwin Creek is in northern Mississippi and is part of the Yazoo River watershed, which subsequently flows into the Mississippi River near Vicksburg, Mississippi. The primary crops in the watershed are cotton and soybean with smaller acreages of grain sorghum and corn. The watershed is dominated by highly erodible silt soils, relatively steep slopes, and high energy rainfall. Most of the cultivation occurs near the streams on the local alluvium. Edge-of-field gullies are common. Channels are deeply incised and are generally oversized for their drainage area. In a number of locations, the streambanks are nearly vertical, are devoid of vegetation and are subject to undercutting and collapse. Annual sediment yields from the watershed average $13.2 \mathrm{Mg} \mathrm{ha}^{-1}(11,700$ $\mathrm{lb} \mathrm{ac} \mathrm{c}^{-1}$ ) and are among the highest in the nation. The major contaminant is stream sediment during storm events and aquatic habitat affected by high sediment concentrations. Three-fourths of the suspended sediment originates from streambanks and channels.

Sediment concentrations responded to decreases in cultivated land. The CRP has promoted a decrease in cultivated acreage from $26 \%$ of the land area to $8 \%$. The shift to less erodible land use reduced runoff amounts originating on upland areas and subsequently reduced channel erosion and sediment transport. The change in land use decreased sediment concentrations in the stream by more than $60 \%$. The application of AnnAGNPS on Goodwin Creek showed that a significant amount of sediment is produced from concentrated flow sources, such as gullies and channels, and that the use of grade control structures in the channels reduced sediment transport substantially (Kuhnle et al. 2008).

Beasley Lake, Mississippi. The Beasley Lake watershed is in western Mississippi and drains into an oxbow lake that was formed from a cutoff meander of the Big
Sunflower River. The drainage area of the watershed is about 915 ha $(370 \mathrm{ac})$ with much of the area in cropland and the remaining area in lake surface and riparian forest. The topography and cropping systems are typical of those throughout the Mississippi Delta region. The primary contaminants in the watershed are sediment, $\mathrm{N}, \mathrm{P}$, and pesticides transported in surface runoff from cropland. The Beasley Lake watershed was a component of the MSEA project; therefore, substantial hydrologic and environmental quality data were available before CEAP began. Land use in the watershed includes cropland (67\%), with cotton and soybean as the primary crops, and CRP (13\%). The soils vary from sandy loam to heavy clay. Since 2001, reduced tillage practices have been used on most of the cotton and soybean production areas. A constructed wetland in the watershed provided an opportunity to assess the potential of the wetland ecosystem to mitigate the movement of contaminants to downstream waters. The Beasley Lake watershed has enabled a study of the effects of conservation practices in fields, at field edges, and in lake ecosystems. These include reduced tillage, CRP, constructed wetlands, vegetated buffer strips, and forest riparian buffers.

The combination of conservation practices used in the Beasley Lake watershed resulted in reduced non-point source agricultural pollutants and was of sufficient magnitude to improve the productivity of the lake during more than 10 years of research studies (Locke et al. 2008). Suspended sediment in the lake was reduced by $70 \%$ and total $\mathrm{P}$ by $40 \%$ following the implementation of conservation practices (e.g., reduced tillage and CRP). Lake water pesticide detections were progressively reduced as management systems progressed from conventional tillage to reduced tillage and CRP. Constructed wetlands have shown promise for removing herbicides and other contaminants from agricultural field runoff. Vegetated edge-of-field buffer strips effectively increased degradation of pesticides and reduced the transport of the pesticides to adjacent waters. The preservation and maintenance of natural forest riparian buffers is an important management practice for reducing the level of agricultural chemicals in surface waters.

The AnnAGNPS model was used on the watershed to simulate water runoff and sediment loss on each field and the resulting impact on water quality in Beasley Lake (Yuan et al. 2008). The model was applied without calibration, and the simulated runoff and sediment yield compared well with observed data. The AnnAGNPS model was used to identify high sediment-producing areas and to simulate the water quality impacts of targeting conservation practices to these areas. Simulation of converting the most erodible $7 \%$ of the watershed from conventional tillage to notill soybean reduced the annual sediment loads to the lake by $15 \%$, while simulating converting $33 \%$ of the most erodible cropland to grassland produced larger reductions in sediment loads (69\%) to the lake than converting the land to no-till soybeans $(54 \%)$.

Yalobusha River/Topashaw Creek, Mississippi. The Yalobusha River is in north central Mississippi and is a tributary of the Mississippi River. The major contaminant in the Yalobusha River is excessive sediment loads due to gully erosion and streambank failure. The problem is in part the consequence of stream channelization in the 1950s and 1960s. The sediment derived from channel instability and streambank erosion has severely degraded stream and riparian habitats.

The primary CEAP study area of the river basin is the Topashaw Creek Canal watershed. The topography of the Topashaw Creek watershed has relatively flat alluvial plains along streams surrounded by forested hillslopes. The land use is $11 \%$ cropland and $80 \%$ forest with the remainder in pasture or grasses, urban area, and wetlands. The soils are mostly loam or silt loam. The primary crops are corn, cotton, sweet potato, and soybean. No-till management is often used for corn and cotton production. Substantial 
cropland area has been converted to grass or forest through CRP.

Gully erosion accounts for about onehalf of the sediment yield in the Topashaw Creek watershed. Environmental Quality Incentives Program funds have been allocated to the watershed since 2003 for gully erosion control. The most common conservation practice for gully erosion is grade control structures using droppipe grade stabilization structures. These drop-pipe structures have substantially reduced the annual sediment yield from the Topashaw Creek watershed (Wilson et al. 2008).

Little River, Georgia. The Little River watershed is in the coastal plain region of southern Georgia. The climate of the area is warm and humid with high rainfall. The region is characterized by low surface relief and high-density stream networks. Dense natural riparian buffers exist along most streams. Land use is about $40 \%$ woodland, $36 \%$ cropland, and $18 \%$ pasture. The primary crops are corn, cotton, and peanuts. The soils are sandy and low in organic matter, and generally require relatively high $\mathrm{N}$ application for successful crop production.

Principalstream contamination includes nutrient enrichment, low dissolved oxygen, fecal coliform and other bacterial indicators, sediment, and pesticides. Conservation practices implemented to reduce this contamination include conservation tillage, cover crops, nutrient and pesticide management plans, installing grassed waterways and terraces, and establishing trees on marginal lands through CRP. Conservation practices have been installed on $16 \%$ of the land area within the watershed with most practices targeted to reduce upland erosion (Bosch et al. 2007; Sullivan and Batten 2007). These practices appear to have produced a slight reduction in sediment yield and nutrient loading from upland fields. Total P showed a significantly decreasing trend over time with the decrease primarily during winter months (Feyereisen et al. 2008). Riparian buffers along the streams have been very effective in filtering out sediment, nutri- ents, and pesticides from runoff water and groundwater before these constituents can enter the stream system (Lowrance et al. 1986). Comparisons between hydrologic simulations using the SWAT and AnnAGNPS models for the Little River watershed have produced encouraging results that show the potential of using the models to quantify the effects of conservation practices (Suttles et al. 2003; Bosch et al. 2004; Van Liew et al. 2007; Feyereisen et al. 2007).

Upper Washita River/Fort Cobb Reservoir, Oklahoma. The Upper Washita River drains about $8,000 \mathrm{~km}^{2}\left(3,100 \mathrm{mi}^{2}\right)$ of predominately agricultural land in west central Oklahoma. Research has centered (1) on the Fort Cobb Reservoir watershed portion of the Upper Washita River watershed because the Fort Cobb watershed has been a focal point for applying conservation practices to improve water quality and (2) on the Little Washita subwatershed where watershed data have been obtained for decades.

Land use within the Fort Cobb watershed is about $56 \%$ cropland (mostly rain-fed) and 33\% pasture and rangeland. The soils in both watersheds are moderately to highly erosive silt loams or fine sandy loams. The pasture, rangelands, and much of the cropland are grazed by cattle, and there are a few swine and cattle confined feeding operations within the watershed. The climate is subhumid with the largest monthly rainfall in the late spring and fall. A primary environmental issue is the movement of sediment and nutrients into water supply reservoirs. Conservation practices implemented on the Fort Cobb watershed include notillage, stream bank fencing, structural practices, water management practices, and converting cropland to grassland. Oklahoma Conservation Commission education and conservation efforts from 1995 to 2002 contributed to decreased loads of pesticides, nutrients, and sediments to the stream and removal of the Lake Creek watershed (subwatershed within the Fort Cobb Reservoir watershed) from the Oklahoma 303(d) list of impaired water bodies (Steiner et al. 2008b).

Gully and channel erosion are significant sources of sediment and nutrients in runoff in the Little Washita River subwatershed. Treatment of gullies by land shaping and vegetation establishment resulted in an $82 \%$ reduction in on-site annual sediment loss, a $61 \%$ reduction in annual total $\mathrm{P}$ loss, and a 56\% reduction in annual total $\mathrm{N}$ loss relative to untreated gullies (Sharpley et al. 1996).

The SWAT model applied to the Upper Washita River showed that flood water retarding structures have substantially reduced peak flow in streams (Van Liew et al. 2003). The Oklahoma Conservation Commission credited such flood retarding structures in Oklahoma with saving millions of dollars of flood damage to agricultural and urban areas during storms in May of 2007.

Analysis of the long-term hydrologic record of the Fort Cobb watershed showed that the wetter, compared to dryer, climatic regimes were characterized by $33 \%$ increase in precipitation, $101 \%$ increase in streamflow, and 183\% increase in sediment yield (Garbrecht et al. 2006; Steiner et al. 2008b). Such persistent precipitation variations could easily mask the effects of conservation practices if not explicitly accounted for in the CEAP assessments.

Leon River, Texas. The Leon River watershed is in central Texas. The watershed drains an area of over $6,000 \mathrm{~km}^{2}$ $\left(2,300 \mathrm{mi}^{2}\right)$ that flows into a large domestic water supply reservoir. The land use is about $68 \%$ pasture and $11 \%$ cropland and contains approximately 100 confined dairy operations. The drainage area of the basin also includes part of a large military base (Fort Hood). There are several small municipalities in the watershed that contribute effluent as point sources into the stream. Mean annual rainfall is about $800 \mathrm{~mm}$ (31 in) with most of the runoffproducing rains in the spring. The major stream contaminants are nutrients and bacteria contributed by the dairies, nonpoint sources, and other point sources. 
The CEAP studies focused on the impacts of conservation practices on water quality and soil quality. The practices involved erosion control, tillage systems, and nutrient management systems. On cropland areas, the incorporation of animal waste (poultry litter) and split application of $\mathrm{N}$ were effective in reducing the downstream load of nutrients. Conservation tillage systems and the establishment of permanent grasses increased the sequestration of carbon in the soil. Management practices installed on Fort Hood include gully plugs and deep ripping. These practices reduced surface runoff and sediment loads (Harmel et al. 2008). The SWAT model was also evaluated on the Leon River watershed. The model was successfully validated for predicting streamflow in the watershed. Validation of SWAT for predicting sediment and nutrient loads in the Leon River is pending (Rossi et al. 2008).

Upper Snake River/Rock Creek, Idaho. The Upper Snake River/Rock Creek watershed is in southern Idaho and is the only ARS benchmark watershed with a majority of irrigated cropland. The watershed drainage area is $6,300 \mathrm{~km}^{2}$ $\left(2,460 \mathrm{mi}^{2}\right)$ with $60 \%$ of the area in forest and $37 \%$ in irrigated cropland. The focus of the CEAP studies in the watershed is on the effects of conservation practices on soil erosion, sediment loads, and nutrients from irrigated cropland. The research focused on the Twin Falls irrigation tract, an $820-\mathrm{km}^{2}\left(320 \mathrm{mi}^{2}\right)$ agricultural area along the south side of the Snake River. The mean annual precipitation in the area is about $290 \mathrm{~mm}$ (11 in). Irrigation, however, contributes about four times more water to the watershed than precipitation. The source of the irrigation water is the Snake River, and approximately 35\% of the water withdrawn for irrigation flows back into the river from irrigation runoff, subsurface drainage, or unused water. The crops irrigated are corn, dry beans, and alfalfa, with smaller acreage of wheat, barley, sugar beet, and potato.

The irrigation tract has historically been furrow irrigated. Much of the area has been converted to sprinkler irrigation with financial assistance through EQIP. In 2006, approximately 40\% of the cropland was sprinkler irrigated. The primary objective of the CEAP studies has been to quantify the environmental effects of converting furrow irrigated areas to sprinkler irrigation. Converting to sprinkler irrigation, installing sediment ponds and using polyacrylamide to reduce erosion have combined to reduce sediment concentrations in return flow by $80 \%$. Similarly, soluble salts in return flow were reduced by 33\%. Preliminary analysis indicates that the irrigation tract is retaining more soluble salts with sprinkler irrigation, thereby reducing salts in return flow to the river but raising the possibility of long-term accumulation of salt within the irrigation tract.

The SWAT and AnnAGNPS models have been evaluated on the watershed with limited success. Neither model was capable of successfully predicting irrigation-induced erosion or irrigation hydrology. The inability of the models to predict sediment and nutrient transport under irrigation conditions limits the opportunity for land managers to select the optimum areas to apply conservation practices and points to the need for model improvements for irrigated conditions (Bjorneberg et al. 2008).

Sediment Source Analysis and Channel Contributions. The USDA erosion control efforts have historically focused on fields and upland areas. On watersheds where conservation practices have successfully controlled erosion from upland field areas, the locus of stream sedimentation may have shifted from fields to channels (Trimble and Lund 1983; Simon and Rinaldi 2000). There is evidence that much of the suspended sediment that adversely impacts water quality and aquatic habitats originates from stream channels. Rapid geomorphic assessments have been performed on selected CEAP watersheds to identify channel contributions to sedimentation relative to channel contributions from stable channels in other watersheds in the same region.
Most of the CEAP watersheds analyzed produced more suspended sediment than stable channels in the same region. On the Fort Cobb and Little Washita watersheds (Oklahoma), channels made a significantly larger contribution to suspended sediment loading than on other watersheds in the region. Stream banks and channels were major contributors to suspended sediment yields on the Town Brook (New York), Goodwin Creek (Mississippi), and South Fork Iowa River (Iowa) watersheds relative to stable systems in the respective regions. Of the five CEAP watersheds analyzed, only the Little River (Georgia) watershed did not have more sediment yield from channel sources than other stable channels in the region. Rapid geomorphic assessments will be performed on the other CEAP watersheds in the future, but these results clearly point to the need to quantify channel and streambank erosion when assessing the effects of conservation practices on stream sediment yield (Simon and Klimetz 2008).

A new technique was developed using naturally occurring radionuclides $\left({ }^{7} \mathrm{Be}\right.$ and $\left.{ }^{210} \mathrm{~Pb}_{\mathrm{xs}}\right)$ to differentiate eroded surface soil from channel-derived sediments in suspended sediment loads. Application of the technique to five CEAP watersheds suggest that surface soils are prevalent in the suspended load early in a runoff event while channel contributions dominate during the later stages (Wilson et al. 2008).

\section{Objective 3 Results: Model Validation and Uncertainty Analysis}

Watershed models are essential tools for estimating the effects of conservation practices at a watershed scale. However, to use models for policy decisions and other applications, the models must be scientifically sound and defensible. Model validation is the process of demonstrating that a model is capable of making sufficiently accurate simulations for the intended purpose. Specific criteria are needed for accepting or rejecting models for specific applications. Moriasi, et al. (2007) developed quantitative guidelines 
for evaluating the performance of models for streamflow, sediment load, and nutrient load estimates. Three quantitative statistics, along with graphical procedures, were recommended. The guidelines were applied using SWAT on the Leon River watershed as a test case. The SWAT validation was good to very good for estimating streamflow on all subbasins of the Leon River. Green et al. (2006) validated SWAT, modified for tile drainage, for predicting streamflow in the South Fork watershed of the Iowa River. The results show that SWAT is a promising tool for evaluating streamflow in tile-drained regions. Yuan et al. (2008) calibrated and validated AnnAGNPS for predicting sediment in the Beasley Lake watershed, demonstrating applicability in extremely flat, poorly drained soils.

Understanding the uncertainty of model estimates is essential to interpreting the results of using models to determine the effects of conservation practices on environmental quality. Uncertainty in model estimates arises from many sources including input data (weather, soil properties, field management information, etc.), model parameters, model processes, and other factors. There is also inherent uncertainty in field data of streamflow and water quality constituents used to calibrate and validate models. Harmel et al. (2006) showed that the "data quality" uncertainty ranged from $6 \%$ to $19 \%$ for streamflow measurements, from $8 \%$ to $110 \%$ for total $\mathrm{N}$ and $\mathrm{P}$, and $7 \%$ to $53 \%$ for total suspended sediment. With this uncertainty in measured data, models should be evaluated relative to the model's ability to produce outputs within the uncertainty limits of the measured data rather than the outputs with low deviations from the measured data (Harmel and Smith 2007).

The SWAT model has been distributed to hundreds of scientists and engineers at universities, government agencies, and consulting firms throughout the world, and several international SWAT training conferences have been held in the past few years. The US Environmental
Protection Agency and the USDA ARS have made SWAT available to state agencies and consultants throughout the nation to evaluate and assess water quality impairments and to assist in developing watershed plans for addressing specific environmental problems.

The AnnAGNPS system has unique capabilities designed specifically for use in watershed conservation planning by USDA NRCS. The Revised Universal Soil Loss Equation (RUSLE) (Renard et al. 1997), used by NRCS to evaluate the degree of erosion on agricultural fields, was incorporated into AnnAGNPS. Ephemeral gully erosion capabilities were also incorporated to simulate the effect of management on sediment produced that provides a distinction from sheet and rill erosion. Subsurface hydrologic components were added that describe tile drainage and lateral subsurface flow processes within individual fields draining to downstream channels. The Conservational Channel Evolution and Pollutant Transport Systems (CONCEPTS) model (Langendoen and Alonso 2008) is an integral component of AnnAGNPS for providing predictions on how channel evolution and pollutant loadings will be affected by bank erosion and failures, streambed buildup and degradation, and streamside riparian vegetation. The Riparian Ecosystem Management Model (REMM) (Lowrance et al. 2000) is used in AnnAGNPS to describe the effects of riparian buffers on water quality at the field scale.

The application of AnnAGNPS on Goodwin Creek (Kuhnle et al. 2008) showed that a significant amount of sediment is produced from concentrated flow sources, such as gullies and channels. The use of AnnAGNPS within the CEAP special emphasis Upper Auglaize watershed in Ohio (Bingner et al. 2006) demonstrated that ephemeral gullies are the dominant source of sediment within the watershed. Additionally, the application of AnnAGNPS in Ohio showed that the use of controlled drainage can be effective in reducing $\mathrm{N}$ loadings. A simu- lation of the Hanalei watershed in Hawaii (Polyakov et al. 2007) showed that, while sheet and rill components were considered by AnnAGNPS, landslide processes were significant contributors to sediment in the watershed, demonstrating the need for additional research to incorporate these processes into watershed models. The ability to account for all sources of sediment and chemicals in watershed models will reduce the uncertainty in using model simulations for estimating the effects of conservation practices.

The SWAT and AnnAGNPS models have been tested, validated, and applied in various ways on many of the ARS benchmark watersheds. Many of the model evaluations have been watershed specific and are described in the objective 2 results section above. (For SWAT, see Walnut Creek, St. Joseph River, Mark Twain Lake/Salt River Basin, Town Brook/ Cannonsville Reservoir, Choptank River, Little River, Upper Washita River, Leon River, and Upper Snake River/Rock Creek watersheds. For AnnAGNPS, see St. Joseph River, Choptank River, Beasley Lake, Little River, and Upper Snake River/Rock Creek watershed.) The AnnAGNPS model was also successfully validated for simulating sediment and nutrient loads in Georgia (Suttles et al. 2003), Ohio (Bingner et al. 2006), Canada (Leon et al. 2005), and sediment in Sicily (Licciardello et al. 2007). Application of AnnAGNPS to the Hanalei watershed in Hawaii showed that landslide processes were significant contributors to sediment yield and need to be incorporated into the model (Polyakov et al. 2007). Overall, the model validation analysis shows that both SWAT and AnnAGNPS are valuable tools for analyzing the impact of conservation practices on environmental quality.

\section{Objective 4 Results: Development of Policy-Planning Tools \\ Watershed-Specific Economics Studies.} Watershed-specific economic studies were conducted on three watersheds: (1) Town Brook/Cannonsville Reservoir, 
New York; (2) St. Joseph, Indiana; and (3) Upper Big Walnut Creek, Ohio.

Town Brook / Cannonsville Reservoir, New York. A farm firm production model for the watershed was developed that included input, output, and practice choices that characterize farm decisions consistent with physical and cultural environments in the Cannonsville watershed. The model was successfully linked to the Integrated Farming Systems Model, which assesses nutrient losses at the field and farm scale. Input data for two farms in the Cannonsville watershed were collected. These data were used to conduct an economic assessment of the costs and benefits associated with adoption of vegetative filter strips, cover crops, soil nutrient management, precision feeding, conservation tillage, and rotational grazing. Results showed that economic conditions (e.g., commodity prices) are parametric inputs to the farm firm production decision model. Components of a farm management plan that are sensitive to economic conditions include: land use and crop production, buying and selling of inputs and outputs, animal feeding strategy, and manure management. Simulated dairy production plans share a number of important characteristics of real production plans, including soybean and corn being produced, crop diversification, and animal feeding using homegrown forages.

St. Joseph River, Indiana. An economic study on the St. Joseph River watershed focused on assessing economic and environmental tradeoffs of changing land use by utilizing conservation tillage and installing buffers. The analysis considered three tillage systems: conventional, reduced, and no-till in a corn and soybean rotation across three different representative farm sizes. The Purdue Crop and Livestock Linear Programming Model was used to estimate the returns from cropping operations. The costs and benefits of installing buffers of various widths and composition were included in the economic analysis to help understand what incentives and barriers exist when firms consider adop- tion of conservation practices. The Water Erosion Prediction Project (WEPP) model was used to estimate sediment yields for the production practices applied in the economic model. The results showed that on marginal lands there is more financial incentive for smaller farms to adopt buffers than for larger farms. Large farms have the ability to produce profitably on marginal lands and may be less inclined to take these lands out of production, while small farms may find economic advantages in placing marginal lands into conservation buffers. Changing tillage practice from conventional or reduced tillage to a no-till system had a dramatic impact on reducing sediment yields, but as buffer widths were increased, the choice of tillage system had less impact on overall sediment yields. Modeling technologies that examine the economic and environmental repercussions of production practices allow the farmers and taxpayers to receive the greatest economic benefit from conservation programs (Cain et al. 2007).

Upper Big Walnut Creek, Ohio. An economic analysis of the benefits of adopting conservation practices in the watershed was conducted. A survey of local residents indicated that water quality improvements in the small streams of the watershed are the most valuable benefit, followed by drinking water benefits and habitat conservation for birds and other upland game. A dynamic optimization model was developed for economic analysis of nutrient abatement in the Upper Big Walnut Creek watershed. The model treats $\mathrm{N}$ in soils, stream segments, and a downstream reservoir as separate stocks to be managed by changing nutrient inputs, changing technology on fields, and changing investments in drainage structures. The model optimizes these choices to maximize the net social benefits of $\mathrm{N}$ inputs, where net social benefits are the net private benefits of crop production less the social damages from $\mathrm{N}$ export. The model was applied to the Hoover Reservoir in the watershed. Based on nutrient application to farm fields only, the nutrient application rate for optimum private profit was found to be $22 \%$ higher than the rate for net private benefits less social damages. Additional analyses that would include in-stream structures are pending (King et al. 2007).

Policy Planning Tools. In planning the CEAP watershed assessment studies, it was recognized that the economic objectives required a modeling system that integrated economic models with physical process models. Further, the modeling system had to be capable of evaluating the trade-offs among multiple objectives. The product from the economic research is a modeling system (now known as the ARS Economic Biophysical Optimization Model) that can calculate the optimum trade-offs among an arbitrary number of objectives, where each objective is specified by an economic model, a physical model or a statistical function. A genetic algorithm (GA) was chosen for the optimization method. Loosely based on Darwinian evolution, the GA finds an optimum by constantly re-evaluating the solution and modifying the model parameters. Where economic and physical models have previously been linked by passing optimum values from one model to the other (Whittaker 2005), the GA allows information to be passed among models during the optimization. Evaluation of trade-offs among objectives has been problematic, and usually relied on weighting each objective (Färe et al 2004). A GA was used that calculates a spread of points that outline the optimum trade-offs among the CEAP economic objectives: farm level profit, environmental quality, and policy efficiency (Whittaker et al. 2007). The method is computationally expensive, so a Beowulf parallel computer cluster was constructed, and all model software was written to run on the parallel computer.

The most notable spinoff applications of this work are the automatic calibration of the SWAT model (Confesor and Whittaker 2007) and the estimation of risk (Whittaker 2004). In the autocalibration for SWAT, more than 130 SWAT variables are simultaneously optimized with the calibration 
routine. This routine allows for the simultaneous automatic calibration of SWAT water quality and quantity parameters and the application of Pareto optimization in economic decision and policy-making problems related to conflicting objectives (Confesor and Whittaker 2007; Whittaker et al. 2007). This work has enabled the integration of the physical models used in CEAP (primarily SWAT) with economics models to provide state-of-the-art tools for conservation policy-planning. Adequate economic data needs to be collected on a number of the USDA ARS benchmark watersheds and other research watersheds before the conservation policy-planning tool can be fully evaluated and expanded risk and uncertainty studies conducted.

\section{Objective 5 Results: Development of Regional Models}

New assessment tools are needed for future CEAP national assessments that will provide sound results across regions of the country. Current models such as SWAT and AnnAGNPS are functional for the original intended use but are difficult to expand to include region-specific physical processes and conservation practices. The goal of this research objective was to develop new computer modeling tools that can be used to quantify the environmental impacts of conservation practices at field to watershed scales and can be customized to address regional issues. An object modeling system (OMS) (Ahuja et al. 2005) with a modular modeling structure has been developed to incorporate a library of models that can be independently evaluated, improved, and substituted. The OMS is being used as the framework for developing nextgeneration models that incorporate: (1) improved simulation of conservation practices and management effects, (2) improved field to watershed scaling techniques, (3) better integration of overland transport and channel processes, and (4) new methods of assessing model uncertainty. A state-of-science OMS component library was developed by USDA ARS and NRCS in partnership with the US Geological Survey.
Twenty-six regions of the country were identified for development of regionspecific models that address processes or issues peculiar to each region. The region selections were based on established land resource regions. A prototype OMS watershed model for the Midwest region of the United States was developed to demonstrate evaluation of the effectiveness of conservation practices on ARS benchmark watersheds in the region. Complex interactions between system components and spatial units are being quantified using the prototype model and field measurements on the watersheds.

\section{Synthesis of Preliminary Findings}

The charge to CEAP is to provide a quantification of the environmental effects of USDA conservation programs. This charge is being executed through a national assessment that is supported by scientific studies. The ARS benchmark watershed studies are providing key elements of the scientific underpinning of CEAP.The heart of the watershed studies is the collection of data on strategically located watersheds. However, definitive results at a watershed scale require many more years of data. The results in this report, as well as the more detailed results in the subsequent reports, are based on only a few years of data and should be viewed as preliminary indications of the findings of the impact of conservation practices on water quality and other indicators of environmental health.

The most lasting legacy of a watershed research program is the basic data that is obtained and available for current and future interpretation. The development and release of STEWARDS as a repository of the watershed data is a significant accomplishment. The STEWARDS system will provide access to a broad spectrum of watershed data at an easily accessible central site and provides an invaluable resource for conducting the national assessment.

The data collected across the 14 ARS benchmark watersheds provide insight and documentation into the effects of selected conservation practices. In some parts of the Midwest, where tile drainage is common, controlled drainage was shown to be an effective practice for reducing $\mathrm{N}$ and $\mathrm{P}$ loads in tile outflows. Constructed wetlands were also shown to substantially reduce the movement of nitrate from tile drained fields into stream systems. Riparian buffers between crop production areas and streams were effective in mitigating the loss of nutrients and bacteria in runoff. Fertilizer management techniques, such as split applications, provided significant reductions in nitrate losses.

The CRP was shown to provide water and soil quality improvements on many of the study watersheds. In the claypan area of Missouri, grass established through CRP provided improved infiltration, thus reducing runoff and erosion losses. In the Mississippi Delta area, the establishment of grass on formerly cultivated areas through CRP reduced runoff and the transport of sediment, nutrients, and pesticides to streams and lakes. Converting cropland to grass in central Oklahoma also substantially lowered the loss of nutrients in runoff. The establishment of cover crops and small grains were effective in reducing nutrient losses to the Chesapeake Bay in Maryland and to streams in Georgia. The establishment of grass in central Texas increased soil quality by raising soil carbon levels.

Natural riparian buffers and constructed vegetated buffer strips have been effective in reducing the transport of nutrients and pesticides from fields to downstream waters. The use of vegetated buffers in conjunction with wetlands and reduced tillage combined to significantly improve the productivity of a lake in Mississippi. Natural riparian buffers in Georgia were effective in improving water quality. Vegetated buffers were also effective in reducing the loss of nutrients and pesticides in Iowa, Missouri, and Mississippi.

Sediment originating from concentrated flow areas such as channels, streambanks, and gullies is a major source of sediment loads and degraded aquatic habitats in some watersheds. Structural 
measures are normally required to reduce sediment transport from these sources. Grade control structures have substantially reduced sediment yield from streams in Mississippi, and gully shaping has reduced sediment loads and associated $\mathrm{P}$ loads in Oklahoma. In irrigated areas of the western US, converting from furrow irrigation to sprinkler irrigation through EQIP has greatly reduced erosion and the loss of soluble salts.

The data collected from the ARS Benchmark watersheds have provided valuable insight into the effects of conservation practices, but it is not possible to adequately quantify the soil and water quality effects on a large scale based on the data alone. Models that are validated based on the data are required to extrapolate the findings to watershed or regional scales. The two primary models to be used in the national assessment, SWAT and AnnAGNPS, were validated using the data from many of the watersheds. The validations have proven the value of the models for simulating streamflow, sediment transport, and the flux of nutrients and pesticides. The potential of the models to address hypothetical questions such as the effects of degree of implementation of practices on a watershed or identification of target areas for conservation practices has been demonstrated. Guidelines were developed for evaluating the models and for defining the uncertainty levels of model estimates. The model studies also identified model deficiencies, such as application to irrigated areas, that need to be addressed as CEAP studies continue. An optimization model was developed that integrates the physical process models (i.e., SWAT and AnnAGNPS) with economics models to evaluate trade-offs among multiple, conflicting objectives. These new innovations in model technology and application provide valuable tools for determining definitive quantification of soil and water quality effects of conservation practices.

Finally, a prototype, next-generation OMS was developed to address regionspecific processes and issues. The OMS model has a modular structure that enables process models to be interchanged to utilize the most appropriate model for a region. The model will provide enhanced modeling capabilities for future assessments of conservation programs.

Collectively, these accomplishments demonstrate that CEAP has been effective in identifying and quantifying the effects of conservation practices, though much work remains to be done to provide more definitive answers on the effectiveness of conservation practices and their value to the US environment, economy, and general public.

\section{References}

Ahuja, L.R., J.C.Ascough II, and O. David. 2005. Developing natural resource models using the Object Modeling System: Feasibility and challenges. Advances in Geosciences 4:29-36.

Arnold, J.G., R. Srinivansan, R.S. Muttiah, and J.R.Williams. 1998. Large area hydrologic modeling and assessment Part I: Model development. Journal of the American Water Resources Association 34(1):73-89.

Baker, L.A. 1992. Introduction to nonpoint source pollution in the United States and prospects for wetland use. Ecological Engineering 1(1-2):1-26.

Bingner, R.L., K. Czajkowski, M. Palmer, J. Coss, S. Davis, J. Stafford, N.Widman, F.D.Theurer, G. Koltun, P. Richards, and T. Friona. 2006. Upper Auglaize Watershed AGNPS Modeling Final Report. Research Report No. 51 Oxford, MS: National Sedimentation Laboratory, USDA Agricultural Research Service.

Bingner R.L., and F.D. Theurer. 2001. AnnAGNPS Estimating sediment yield by particle size for sheet \& rill erosion. Proceedings of the Seventh Interagency Sedimentation Conference, Reno, NV, March 25-29, 2001.Vol. 1(I):1-7.

Bishop, P. 2006. Update on phosphorus loading from WBDR basin. Working paper. Albany, NY: Division of Water, Bureau of Water Assessment and Management, New York State Department of Environmental Conservation.

Bjorneberg, D.L., D.T. Westermann, N.O. Nelson, and J.H. Kendrick. 2008. Conservation practice effectiveness in the irrigated Upper Snake River/Rock Creek watershed. Journal of Soil and Water Conservation 63(6):487-495.

Bosch, D.D., J.M. Sheridan, H.L. Batten, and J.G. Arnold. 2004. Evaluation of the SWAT model on a coastal plain agricultural watershed. Transactions of the ASABE 47(5):1493-1506.

Bosch, D.D., J.M. Sheridan, R.R. Lowrance, R.K. Hubbard, T.C. Strickland, and D.G. Sullivan. 2007. Little River Experimental Watershed database. Water Resources Research 43:W09470. doi:10.1029/2006WR005844.

Bryant, R.B., T.L. Veith, P.J.A. Kleinman, and W.J. Gburek. 2008. Cannonsville Reservoir and Town Brook watersheds: Documenting conservation effects to protect New York City's drinking water. Journal of Soil and Water Conservation 63(6):339-344.

Cain, Z., S. Lovejoy, J. Frankenberger, D. Flanagan, and J. Lee. 2007. Adoption of conservation initiatives on Midwes farms: Farm size matters. Working paper. West Lafeyette, IN: Purdue University.
Chishester, F.W., and C.W. Richardson. 1992. Sediment and nutrient loss from clay soils as affected by tillage. Journal of Environmental Quality 21(4):587-590.

Confesor, R.B. Jr., and G.W. Whittaker. 2007. Automatic calibration of hydrologic models with Multi-Objective Evolutionary Algorithm and Pareto Optimization. Journal of the American Water Resources Association 43(4):981-989.

Cox, C. 2006. Foreword. In Environmental Benefits of Conservation on Cropland: The Status of Our Knowledge, ed. M. Schnepf and C. Cox. Ankeny, IA: Soil and Water Conservation Society.

Cox, C. 2007. Foreword. In Managing Agricultural Landscapes for Environmental Quality: Strengthening the Science Base, ed. M. Schnepf and C. Cox. Ankeny, IA: Soil and Water Conservation Society.

Du, B., J.G. Arnold, A. Saleh, and D.B. Jaynes. 2005 Development and application of SWAT to landscapes with tiles and potholes. Transactions of the ASAE 48(3):1121-1133

Du, B.,A. Saleh, D.B. Jaynes, and J.G.Arnold. 2006. Evaluation of SWAT in simulating nitrate nitrogen and atrazine fates in a watershed with tiles and potholes. Transactions of the ASABE 49(4):949-959.

Färe, R., S. Grosskopf, and G. Whittaker. 2004. On value efficiency and data envelopment analysis. Indian Economic Review 39(1):81-88.

Feyereisen, G.W., R.R. Lowrance, T.C. Strickland, D.D. Bosch, and J.M. Sheridan. 2008. Long-term stream chemistry trends in the southern Georgia Little River Experimental Watershed. Journal of Soil and Water Conservation 63(6):475-486.

Feyereisen, G.W., T.C. Strickland, D.D. Bosch, and D.G. Sullivan. 2007. Evaluation of SWAT manual calibration and input parameter sensitivity in the Little Rive Watershed. Transactions of the ASABE 50(3):843-855.

Garbrecht, J.D., P.J. Starks, and J.L. Steiner. 2006. The underappreciated climate factor in CEAP. Journal of Soil and Water Conservation 61(4):110A-112A.

Green, C.H., M.D. Tomer, M. Di Luzio, and J.G. Arnold 2006. Hydrologic evaluation of the Soil and Water Assessment Tool for a large tile-drained watershed in Iowa. Transactions of the ASABE 49(2):413-422.

Harmel, R.D., R.J. Cooper, R.M. Slade, R.L. Haney, and J.G. Arnold. 2006. Cumulative uncertainty in measured streamflow and water quality data for small watersheds. Transactions of the ASABE 49(3):689-701.

Harmel, R.D., C.G. Rossi, T. Dybala, J.G. Arnold, K. Potter J. Wolfe, and D. Hoffman. 2008. Conservation Effects Assessment Project research in the Leon River and Riesel watersheds. Journal of Soil and Water Conservation 63(6):453-460

Harmel, R.D., and P.K. Smith. 2007. Consideration of measurement uncertainty in the evaluation of goodnessof-fit in hydrologic and water quality modeling. Journal of Hydrology 337:326-336.

Heathman, G.C., D.C. Flanagan, M. Larose, and B.W. Zuercher. 2008. Application of the Soil and Water Assessment Tool and Annualized Agricultural NonPoint Source models in the St. Joseph River watershed. Journal of Soil and Water Conservation 63(6):552-568.

Jaynes, D.B., J.L. Hatfield, and D.W. Meek. 1999. Water quality in Walnut Creek Watershed: Herbicides and nitrate in surface waters. Journal of Environmental Quality 28(1):45-58.

King, K.W., N.R. Fausey, S. Surendrannair, and B. Sohngen. 2007. Optimal management of non-point source pollution from agriculture: An application of dynamic programming. Soil and Water Conservation Society 2007 Annual Conference Final Program and Abstract Book. Ankeny, IA: Soil and Water Conservation Society. King, K.W., P.C. Smiley Jr., B.J. Baker, and N.R. Fausey. 2008 Validation of paired watersheds for assessing conservation 
practices in Upper Big Walnut Creek watershed, Ohio. Journal of Soil and Water Conservation 63(6):380-395.

Knisel, W.G., ed. 1980. CREAMS: A Field Scale Model for Chemicals, Runoff, and Erosion from Agricultural Management Systems. USDA Conservation Research Report No. 26. Washington, DC: USDA Agriculture Research Service.

Kuhnle, R.A., R.L. Bingner, C.V.Alonso, C.G.Wilson, and A Simon. 2008. Conservation practice effects on sediment load in the Goodwin Creek Experimental Watershed. Journal of Soil and Water Conservation 63(6):496-503.

Langendoen, E.J., and C.V.Alonso. 2008. Modeling evolution of incised streams: I. Model formation and validation of flow and streambed evolution components. Journal of Hydraulic Engineering 134(6):749-762.

Larose, M., G.C. Heathman, L.D. Norton, and B. Engle. 2007. Hydrologic and atrazine simulation on the Cedar Creek watershed using the SWAT model. Journal of Environmental Quality 36(2):521-531.

Leon, L.F., J. Imberger, R.E.H. Smith, R.E. Hecky, D.C.L. Lam, and W.M. Schertzer. 2005. Modeling as a tool for nutrient management in Lake Erie: A hydrodynamics study. Journal of Great Lakes Research 31(Supplement 2):309-318

Lerch, R.N., E.J. Sadler, N.R. Kitchen, K.A. Sudduth, R.J. Kremer, D.B. Myers, C. Baffaut, S.H. Anderson, and C. H. Lin. 2008. Overview of the Mark Twain Lake/Salt River Basin Conservation Effects Assessment Project. Journal of Soil and Water Conservation 63(6):345-359.

Licciardello, F., D.A. Zema, S.M. Zimbone, and R.L. Bingner. 2007. Runoff and soil erosion evaluation by the AnnAGNPS model in a small Mediterranean watershed. Transactions of the ASABE 50(5):1585-1593.

Locke, M.A., S.S. Knight, S. Smith Jr., R.F. Cullum, R.M. Zablotowics, Y. Yuan, and R.L. Bingner. 2008 Environmental quality research in the Beasley Lake watershed, 1995 to 2007: Succession from conventional to conservation practices. Journal of Soil and Water Conservation 63(6):430-442.

Lowrance, R.R., L.S. Altier, R.G. Williams, S.P. Inamdar, J.M. Sheridan, D.D. Bosch, R.K. Hubbard, and D.L. Thomas. 2000. REMM: The riparian ecosystem management model. Journal of Soil and Water Conservation $55(1): 27-34$

Lowrance, R.R., J.K. Sharpe, and J.M. Sheridan. 1986 Long-term sediment deposition in the riparian zone of a Coastal Plain Watershed. Journal of Soil and Water Conservation 41(4):266-271.

McCarty, G.W., L.L. McConnell, C.J. Hapeman, A. Sadeghi, C. Graff, W.D. Hively, M.W. Lang, T.R. Fisher, T. Jordan, C.P. Rice, E.E. Codling, D. Whitall, A. Lynn, J. Keppler, and M.L. Fogel. 2008. Water quality and conservation practice effects in the Choptank River watershed. Journal of Soil and Water Conservation 63(6):461-474.

Missouri Department of Natural Resources. 1998. Section 303(d) Waters. Sept. 23, 1998, amended by USEPA Apri 17, 1999. Jefferson City, MO: Missouri Department of Natural Resources.

Moriasi, D.N., J.G.Arnold, M.W.Van Liew, R.L. Bingner, R.D. Harmel, and T.L.Veith. 2007. Model evaluation guidelines for systematic quantification of accuracy in watershed simulations. Transactions of the ASABE 50(3):885-900.

Ohio Environmental Protection Agency. 2003. Biological and Water Quality Study of the Big Walnut Creek Basin 2000, Delaware, Fairfield, Franklin, Licking, Morrow, and Pickaway Counties, Ohio. OEPA Technical Report DSW/EAS 2003-11-10. Columbus, OH: Division of Surface Water, Ohio Environmental Protection Agency.

Ohio Environmental Protection Agency. 2004.Total Maximum Daily Loads for the Big Walnut Creek Watershed. Draft Report. Columbus, OH: Division of Surface Water, Ohio Environmental Protection Agency.

Pappas, E.A., C. Huang, and D.L. Bucholtz. 2008. Implication of sampling frequency to herbicide conservation effects assessment. Journal of Soil and Water Conservation 63(6):410-419.

Phillips, D.L., P.D. Hardin, V.W. Benson, and J.V. Bagilo. 1993. Nonpoint source pollution impacts of alternative agricultural management practices in Illinois: A simulation study. Journal of Soil and Water Conservation 48(5):449-457.

Polyakov, A., A. Fares, D. Kubo, J. Jacob, and C. Smith. 2007. Evaluation of a non-point source pollution model, AnnAGNPS, in a tropical watershed. Environmental Modeling and Software 22(11):1617-1627.

Renard, K.G., G.R. Foster, G.A.Weesies, D.K. McCool, and D.C Yoder. 1997. Predicting Soil Erosion by Water: A Guide to Conservation Planning with the Revised Universal Soil Loss Equation (RUSLE). USDA Agricultural Handbook No. 703. Washington, DC: USDA

Rossi, C.G., T.J. Dybala, D.N. Moriasi, J.G. Arnold, C. Amonett, and T. Marek. 2008. Hydrologic calibration and validation of the Soil and Water Assessment Tool for the Leon River watershed. Journal of Soil and Water Conservation 63(6):533-541.

Sadler, E.J., J.L. Steiner, J.-S. Chen, G. Wilson, J. Ross, T. Oster, D. James, B. Vandenberg, and J. Hatfield. 2008. Sustaining the Earth's Watersheds-Agricultural Research Data System: Data development, user interaction, and operations management. Journal of Soil and Water Conservation 63(6):577-589.

Saleh, A., E. Osei, D.B. Jaynes, B. Du, and J.G. Arnold. 2007. Economic and environmental impacts of LSNT and cover crops for nitrate-nitrogen reduction in Walnut Creek Watershed, Iowa using FEM and enhanced SWAT models. Transactions of the ASABE 50(4):1251-1259.

Sharpley, A., S.J. Smith, J.A. Zollweg, and G.A. Coleman. 1996. Gully treatment and water quality in the Southern Plains. Journal of Soil and Water Conservation 51(6):498-503.

Simon, A., and L. Klimetz. 2008. Relative magnitudes and sources of sediment in benchmark watersheds of the Conservation Effects Assessment Project. Journal of Soil and Water Conservation 63(6):504-522.

Simon, A., and M. Rinaldi. 2000. Channel instability in the loess area of the Midwestern United States. Journal of the American Water Resources Association 36(1):133-150.

Smiley, P.C. Jr., R.B. Gillespie, K.W. King, and C. Huang. 2008. Contribution of habitat and water quality to the integrity of fish communities in agricultural drainage ditches. Journal of Soil and Water Conservation 63(6):218A-219A

Smith, D.R., S.J. Livingston, B.W. Zuercher, M. Larose, G.C. Heathman, and C. Huang. 2008. Nutrient losses from row crop agriculture in Indiana. Journal of Soil and Water Conservation 63(6):396-409.

Smith, R.W., and R.C. Henderson, 1961. Some Interpretations of Runoff and Erosion from Terraces on Blackland Soil. ARS 41-42. Washington, DC: USDA.

Steiner, J.L., D.C. Goodrich, S. Hardegree, M.R. Burkart, T.C. Strickland, and M.A. Weltz. 2003. Information technology applications in the ARS watershed network. In First International Conference on Research in the Watersheds, October 27-30, 2003, ed. K.G. Renard, 62 67. USDA Agricultural Research Service.

Steiner, J.L., E.J. Sadler, J.-S. Chen, G. Wilson, D. James, B. Vandenberg, J. Ross, T. Oster, and K. Cole. 2008a Sustaining the Earth's Watersheds-Agricultural Research Data System: Overview of development and challenges. Journal of Soil and Water Conservation 63(6):569-576.

Steiner, J.L., P.J. Starks, J.A. Daniel, J.D. Garbrecht, D. Moriasi, S. McIntyre, and J.-S. Chen. 2008b. Environmental effects of agricultural conservation: A framework for research in two watersheds in Oklahoma's UpperWashita River Basin. Journal of Soil and Water Conservation 63(6):443-452

Stone, K.C., P.G. Hunt, J.M. Novak, and M.H. Johnson. 2003. In-stream wetland design for non-point source pollu- tion abatement. Applied Engineering in Agriculture 19(2):171-175

Sullivan, D.G., and H.L. Batten. 2007. Little River Experimental Watershed, Tifton, Georgia, United States: A historical geographic database of conservation practice implementation. Water Resources Research 43: W09475. doi:10.1029/2007WR006143.

Suttles, J.B., G. Vellidis, D.D. Bosch, R. Lowrance, J.M. Sheridan, and E.L. Usery. 2003. Watershed-scale simulation of sediment and nutrient loads in Georgia Coastal Plain streams using the annualized AGNPS model. Transactions of the ASAE 46(5):1325-1335.

Tomer, M.D., D.W. Meek, D.B. Jaynes, and J.L. Hatfield. 2003. Evaluation of nitrate nitrogen fluxes from a tile-drained watershed in central Iowa. Journal of Environmental Quality 32(2):642-653.

Tomer, M.D., T.B. Moorman, and C.G. Rossi. 2008a Assessment of the Iowa River's South Fork watershed: Part 1. Water quality. Journal of Soil and Water Conservation 63(6):360-370.

Tomer, M.D., T.B. Moorman, D.E. James, G. Hadish, and C.G. Rossi. 2008b. Assessment of the Iowa River's South Fork watershed: Part 2. Conservation practices. Journal of Soil and Water Conservation 63(6):371-379.

Trimble, S.W., and S.W. Lund. 1983. A sediment budget for Coon Creek Basin in the Driftless Area,Wisconsin, 1853 1977. American Journal of Science 283(5):454-474.

USDA. 1994. Water Quality Research Plan for Management Systems Evaluation Areas. Agricultural Research Service Bulletin ARS-123, Washington, DC: USDA Agricultural Research Service.

US Environmental Protection Agency. 1997. National Water Quality Inventory: 1996 Report to United States Congress. EPA841-R-97-005. Washington, DC: US Environmental Protection Agency.

Van Liew, M.W., J.D. Garbrecht, and J.G. Arnold. 2003 Simulation of the impacts of flood retarding structures on streamflow for a watershed in southwestern Oklahoma under dry, average, and wet climatic conditions. Journal of Soil and Water Conservation 58(6):340-348.

Van Liew, M.W., T.L. Veith, D.D. Bosch, and J.G. Arnold. 2007. Suitability of SWAT for the Conservation Effects Assessment Project: Comparison on USDA Agricultural Research Service watersheds. Journal of Hydrologic Engineering 12(2):173-189.

Wendt, R.C., and R.E. Burwell. 1985. Runoff and soil losses for conventional, reduced, and no-till corn. Journal of Soil and Water Conservation 40(5):450-454.

Whittaker, G. 2004. Use of a Beowulf cluster for estimation of risk using SWAT. Agronomy Journal 96(5):1495-1497.

Whittaker, G. 2005. Application of SWAT in the evaluation of salmon habitat remediation policy. Hydrological Processes 19(3):839-348.

Whittaker, G., R.C. Confesor, S.M. Griffith, R. Färe, S. Grosskopf, J.J. Steiner, G.W. Mueller-Warrant, and G.M. Banowetz. 2007. A hybrid genetic algorithm for multiobjective problems with activity analysis-based local search. European Journal of Operational Research doi:10.1016/j.ejor.2007.10.050.

Wilson, C.G., R.A.Kuhnle,D.D.Bosch, J.L. Steiner, PJ.Starks, M.D.Tomer, and G.V.Wilson. 2008. Quantifying relative contributions from sediment sources in Conservation Effects Assessment Project watersheds. Journal of Soil and Water Conservation 63(6):523-532.

Wilson, G.V., F.D. Shields Jr., R.L. Bingner, P. Reid-Rhoades, D.A. DiCarlo, and S.M. Dabney. 2008. Conservation practices and gully erosion contributions in the Topashaw Canal watershed. Journal of Soil and Water Conservation 63(6):420-429.

Yuan, Y., M.A. Locke, and R.L. Bingner. 2008. Annualized Agricultural Non-Point Source model application for Mississippi Delta Beasley Lake watershed conservation practices assessment. Journal of Soil and Water Conservation 63(6):542-551. 